\title{
Diet selection by grazing animals
}

\author{
B Y JOHN A. MILNE \\ Macaulay Land Use Research Institute, Pentlandfield, Roslin, Midlothian EH25 9RF
}

The subject of diet selection by grazing animals is a vast one. Whilst it is widely accepted that there may be a set of generalized principles underlying foraging behaviour and diet selection by grazing animals, the current philosophy is to develop appropriate models to describe the grazing behaviour for observed sets of specific food distributions and grazers rather than to attempt to seek a generalized foraging theory. The present paper follows this current philosophy in considering only large vertebrate grazing herbivores, and specifically ruminants, within the context of predominately temperate pastures. The domesticated ruminant animals which have been studied most frequently, i.e. cattle, sheep, deer and goats, have adopted slightly different foraging strategies along the continuum of grazers, mixed grazers/browsers and browsers with cattle considered as grazers and goats being the nearest species to a browser. There are a number of animal variables which influence these foraging strategies and they can be seen as adaptations to particular diets which have arisen over evolutionary time or as a result of selection imposed by man (Gordon \& Iason, 1989).

\section{ANIMAI. FACTORS INFLUENCING DIET SELECTION}

Possibly the most all-persuasive variable is the body size of the ruminant. Absolute feed requirements, the inability of fine-grained food selection and retention time in the gut all increase with body-weight (Gordon \& Illius, 1988; Illius \& Gordon, 1987). Larger animals ingest food of potentially lower nutritive value (Hodgson, 1981). Rumen size relative to body size also differs between different species and this is in part responsible for changes in digestive capability for fibrous grasses and trees and shrubs (Demment \& Van Soest, 1985). In general terms, ruminants with a large body size will digest fibrous foods better because of relatively larger rumens and longer retention times, whilst small ruminants will digest fibrous feeds less well because of shorter retention times and rely on foraging strategies which allow it to ingest a diet with a high cell content. Although the grazer-browser continuum and that of body size are correlated there are exceptions, but it should be clear that foraging strategy, diet selection and digestive ability are linked. An example of where the effect of retention time or rumen size on digestive capability does not hold is in the more efficient digestion of heather (Calluna vulgaris) by deer than by sheep (Milne et al. 1978). These findings can be explained by the higher proline content of the saliva of deer than sheep, which reduces the impact of the complexing effect of the tannins found in heather on protein availability in the rumen (Robbins et al. 1987). The role of such secondary compounds in plants in terms of their potentially multifaceted role in influencing diet selection is a fascinating one which is currently being actively studied.

The size and shape of the ruminants' mouthparts also affect its ability to select discrete food items (Gordon \& Illius, 1988). A wide and flat muzzle width is often associated with a low degree of selectivity while feeding, such as in cattle, whilst a narrower and more pointed dental arcade is usually related to a high degree of selectivity, such as in the goat. 
The extent to which diet selection is altered by the metabolic state of the animal has not been studied in any detail. Whilst fatness of sheep has been found to reduce herbage intake, and lactation to stimulate herbage intake (Milne et al. 1981; Gunn et al. 1990), mainly through increases in grazing time rather than in the bite rate or bite mass, the effect of physiological state on diet selection has not been studied either with simple swards or where choices can be made. Since there is no evidence on simple swards of changes in bite rate or bite mass, which are the variables most likely to lead to differences in diet selection, as a result of differences in these metabolic states, it is more likely that effects of metabolic state on diet selection will be manifested in more complex swards where there is a degree of choice. The development of hunger by the penning of animals for periods up to $12 \mathrm{~h}$ without food, which can be considered as an alteration in metabolic state, has been found to alter the composition of the diet of sheep (Arnold et al. 1964), but this is the only direct evidence on the effect of metabolic state on diet selection.

Experience may also be important in influencing the foraging behaviour of sheep, cattle and goats (Arnold, 1970; Hodgson, 1971; Provenza \& Malechek, 1986) with more time being spent foraging and with less food being ingested. Flores et al. (1989a,b) provided more detailed evidence that previous experience by lambs can influence bite rate and bite size on grasses and shrubs differing in maturity and plant form. Convincing evidence on the effects of experience on changes in diet selection, however. is not available. Social learning can be important in the development of food preferences, for example in lambs offered supplementary feeding at pasture (Lobato et al. 1980; Lynch et al. 1983), but its effect on diet selection by grazing ruminants has not been studied.

\section{SWARD FACTORS INFLUENCING DIET SELECTION}

The spatial arrangement of herbage in three dimensions gives herbivores a wide range of opportunities for diet selection. Even in a simple grass-clover (Trifolium repens) sward, there are choices in the horizontal plane between areas of herbage which differ in species composition, nutritive value and height. In more complex situations, such as those found in semi-natural vegetation communities, large-scale mosaics provide variations in species, height and nutritive value, whilst even in relatively small areas of rushes growing in hill-grass pastures, such as Agrostis-Festuca swards, similar levels of complexity can exist. In all these circumstances the animal can make choices between the site at which it grazes. The subject of 'site location' will be considered later.

Grazing animals can also select within the vertical plane of the sward between different plant parts of the same species or different species. An example of this can be found in grass-clover swards, which, although they appear relatively homogenous in the horizontal plane, have considerable variation in grass leaf and stem and clover leaf and petiole in the vertical plane. Selection within this plane is often referred to as 'bite selection'.

\section{BITE SELECTION}

The bite dimensions of interest are depth, area and volume, the product of bite depth and area (see Fig. 1). In simple grass swards grazed by sheep, bite depth is strongly positively correlated with sward surface height (Barthram \& Grant, 1983). Burlison et al. (1990) found that bite area was related negatively to the density of grass tillers, which suggests that bite area is restricted by a limiting maximum force expenditure per bite. 


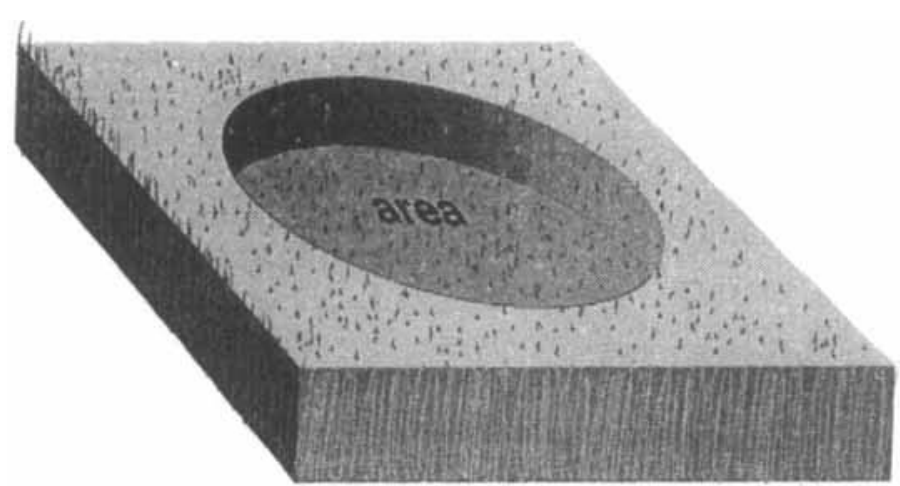

Fig. 1. Diagramatic representation of bite dimensions (from Burlison, 1987).

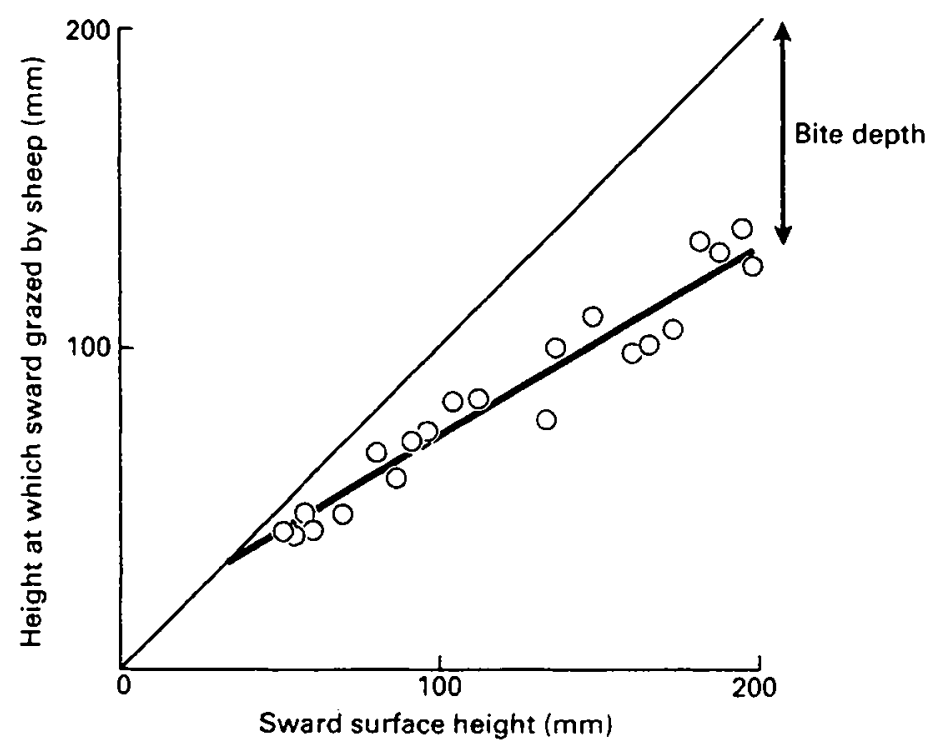

Fig. 2. Relationship between surface height of a perennial ryegrass (Lolium perenne)-white clover (Trifolium repens) sward and the height at which the sward is grazed by sheep (Milne et al. 1982). The difference between the line describing this relationship and the line with a slope of unity is bite depth.

Bite depth was found to be a more important determinant of bite volume than bite area. In considering the relationship between bite weight, which has obvious relationships with bite selection, and surface height and grazed stratum bulk density, it was found that these variables acted independently and that there was a simple additive planar response surface.

If we now consider a more complex situation where clover has been added to a grass sward, the positive relationship between sward surface height and grazing depth is very similar (Milne et al. 1982; see Fig. 2). If one simply looks at the relationship between the proportion of clover in the sward and the proportion of clover in the diet, it is clear that 

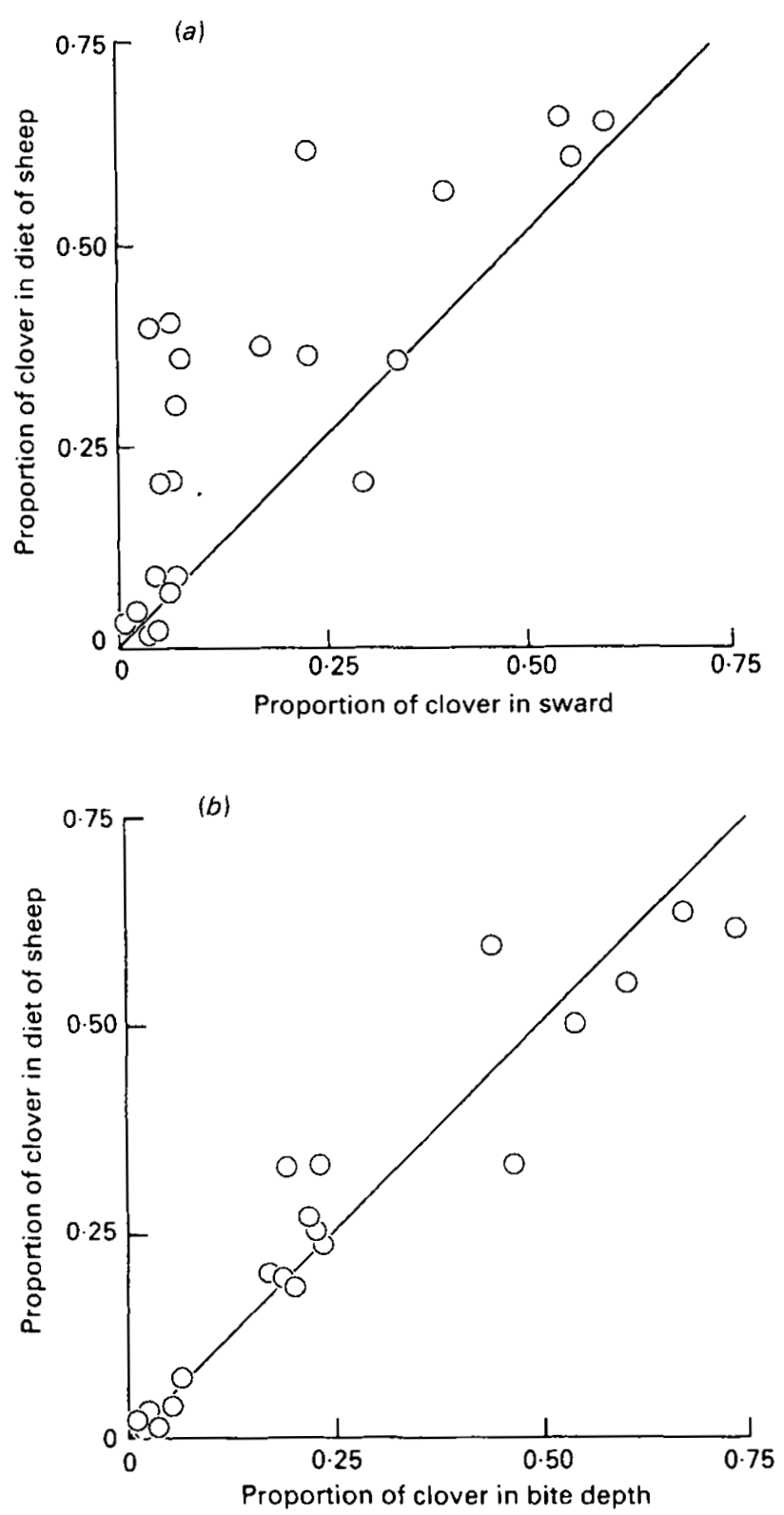

Fig. 3. Relationship between (a) the proportion of white clover (Trifolium repens) in a perennial ryegrass (Lolium perenne)-white clover sward and the proportion in the diet of sheep and (b) the proportion of white clover in the grazed horizon of the same sward and the proportion in the diet of sheep (Milne et al. 1982).

there appears to have been selection for clover (see Fig. 3(a)). However, taking into account the relationship between the bite depth and sward surface height and examining the actual horizon grazed by sheep, evidence for selection is considerably less, with the height of the surface of the sward explaining most of the variation in proportion of clover in the diet (Milne et al. 1982; see Fig. 3(b)). Further examination of the findings, 
however, yielded additional insight into the process of selection for clover. Observations were made over 3 weeks with the proportion of clover in the sward remaining the same, but the proportion of clover at the top of the sward increasing with time, and as would be expected, proportion in the diet also increasing with time. When the relationships between clover in the diet and clover in the grazed horizon of the sward for the 3 weeks were examined, it was found that at low levels of clover in the grazed horizon, there was selection for clover, and at high levels of clover in the grazed horizon there was selection against clover. This phenomenon has been observed in other situations and has led to the development of hypotheses that in foraging circumstances where partial consumption of feeds is taking place, for example, as in most grazing circumstances, animals need to sample food by consumption because other cues of diet selection are either short-lived or inadequate. These hypotheses presume that the animal is not indifferent to the making of choices between alternative feeds.

Before the extent to which bite selection can be influenced by cues is considered, it is worthwhile examining how bite selection by sheep is influenced in a different uniform plant community such as heather. The important difference between the morphology of heather and grass is that growth takes place from the apex of the plant, rather than at the base and that the plant tissue of heather is generally more lignified. The sheep, interestingly, more than deer or goats, graze predominantly only the tops of the shoots unless at a high grazing pressure, eat less of the shoot in the summer than in the autumn, and eat more from younger plants and from those plants that have been previously grazed (Milne et al. 1979). Thus, sheep grazing heather adapt the height at which they select their diet to a much greater extent than when grazing grasses, reflecting the differences in ontology and chemical composition between these plant species. The diet selection of heather can be explained on the basis of a limiting maximum force expenditure per bite in a similar manner to that described for grasses (Burlison et al. 1990). The conclusions that can be drawn from this example are that, although the processes determining bite selection may be the same for different plant species, bite selection will depend greatly on the morphology of the plant and its growth form. The work involved and precision in diet selection also, may differ between plant species being, in this example, greater in a heather than in grass-clover sward.

Let us return to address the question as to what extent the animal uses information obtained by sight, smell, touch and taste cues. A caveat has to be entered at this stage. Since the ruminant may be taking $10-40000$ bites from vegetation daily, the ability to gain and process information is likely to be complex and the monitoring of individual bite choices by the animal difficult. Evidence from studies in which one or more of the special senses has been impaired suggests that taste is likely to be more important than sight, smell or touch in influencing bite selection (Table 1). These results are in line with the hypothesis that sampling of vegetation has an important role to play in bite selection. The role of experience has not been examined at the bite selection level.

\section{SITE SELECTION}

There are a number of factors associated with the vegetation as well as factors such as climate, topography and aspect which influence site selection through effects on the energy expenditure of ruminants. It has been argued from an optimal foraging point of view that site selection should be based on choosing those patches of plant material 
Table 1. Relative preference indices for three grasses when sheep grazed summer range in the United States, the special senses being impaired independently (from Krueger et al. 1974)

\begin{tabular}{lccc}
\hline \hline & $\begin{array}{c}\text { Alpine timothy } \\
\text { (Phleum alpintim) }\end{array}$ & $\begin{array}{c}\text { Mountain brome } \\
\text { (Bromus marginatus) }\end{array}$ & $\begin{array}{c}\text { Onion grass } \\
\text { (Melica spectabilis) }\end{array}$ \\
\hline Control & 1.2 & 2.0 & 1.5 \\
Sight impaired & 1.8 & 2.4 & 2.0 \\
Smell impaired & 1.4 & 1.5 & 1.7 \\
Touch impaired & 1.4 & 2.4 & 1.9 \\
Taste impaired & 0.2 & 0.8 & 1.1 \\
\hline
\end{tabular}

which produced the highest nutrient intake rates for minimum energy expenditure. This has been tested in an experiment conducted by D. Clark, A. W. Illius and J. Hodgson (unpublished results) reported in Illius \& Gordon (1989) in which height of perennial ryegrass (Lolium perenne) sward, which is known to have a positive relationship with nutrient intake rate, was varied. A range of paired height comparisons, $20 v .40,20 v$. 80 , 40 v. $80,80 v .160,80 v .320,160 v .320,20 v .20$ and $80 v .80 \mathrm{~mm}$ were grazed by sheep, goats and cattle and the time that each species spent grazing each patch of different height, as an index of energy expenditure, was observed. Intake rates were also measured and increased by a factor of 2 over the range of sward heights. The taller swards were generally preferred by all species. Sheep showed the lowest sensitivity to height or intake rate in grazing time with goats being most sensitive. Goats were found to have a different grazing style from sheep and cattle, taking shallower bites from the sward surface, indicating their background as a browsing species. The results on the time-period spent grazing patches of different height can be interpreted on the basis of theoretical considerations as the choices of animals which have relatively moderate-togood information about the relative values of alternatives. This information could have been obtained from the short periods that the animals were observed to spend on high frequency sampling of the shorter sward. This provides evidence for site selection as well as for bite selection being influenced by a process of sampling by consumption. For bite selection, taste and force required to obtain the bite were argued to be important and information at the bite level may be important in determining what occurs at the site level of selection.

The experiment described previously showed that differences in intake rate of material, which had basically the same nutrient density, were important in determining site preference. Obviously, such approaches can be used to examine critically the effects of such factors as patch size and distance between patches on site selection. The semi-natural vegetation communities provide patchworks with much greater diversity in such variables as size, height, nutrient density and species. Prediction of site selection in these circumstances is in its infancy and, whilst it will eventually be possible, it will take some time to achieve. Hunter (1962) described the comparative grazing intensity of sheep across the season for a hill which contained Agrostis-Festuca communities, which are of high nutrient density for part of the year, Nardus stricta, a species of moderate-tolow nutrient density and heather, which has a low nutrient density. There was no control over height or biomass of the communities. He considered nutrient density and 


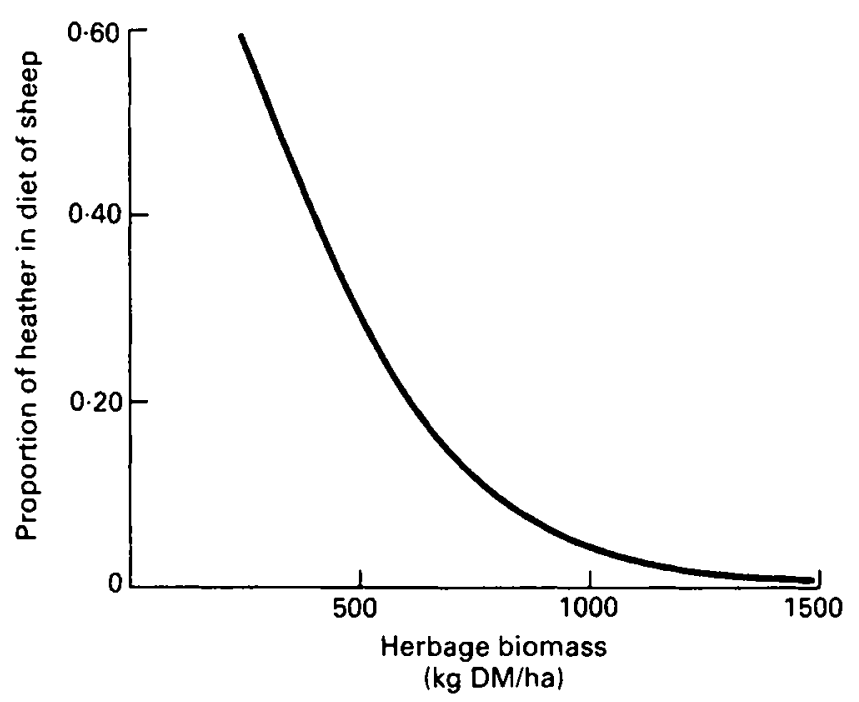

Fig. 4. Relationship between the herbage biomass of a grass pasture in an area containing $0 \cdot 25$ grass pasture and 0.75 heather (Calluna vulgaris) and the proportion of heather in the diet of sheep (from Milne \& Grant, 1987). DM, dry matter.

availability to be the most important factors determining site selection. Information on the grazing behaviour of cattle, deer, goats and ponies on the Island of Rhum, Scotland, obtained by Gordon (1989) can be interpreted in a similar manner. The grazing behaviour of the red deer (Cervus elaphus) was in many ways similar to sheep with both species having relatively large incisor breadth:metabolic requirements such that they grazed on grass swards of high nutrient density whilst they were available. Cattle with a larger body size, longer digesta passage rates and smaller incisor breadth:metabolic requirements also fed on high nutrient-dense grasses but appeared more prepared to eat grasses of lower nutrient density but not heath species. Goats grazed herbage with a high cell wall content either as grasses or heather and, interestingly, seemed to have a requirement for lignified fibrous feeds. These differences between species in site selection require further exploration.

The approach, described previously, is only applicable to the area being studied. What is required is a more fundamental approach, examining the interaction between nutrient density and availability on the site selection more systematically. Such an approach has been adopted with grass-heather combinations where the grass biomass per unit area has been varied and the proportion of the less-preferred species, heather, in the diet of sheep examined. Fig. 4 shows the curvilinear relationship found between grass biomass and proportion of heather in the diet. A similar relationship has also been described when sheep graze plant communities with Nardus and Agrostis-Festuca associations, where Nardus is the less-preferred species (Grant \& Hodgson, 1986). By developing an understanding of such relationships, a framework of understanding of site selection can be set in place.

What cues are used in determining site selection? Of the pre-ingestion cues, as might be expected, sight is the only one for which there is any strong evidence. Post-ingestion 
cues might be considered more important but there is no experimental evidence to support their importance in determining site selection in grazing situations. Previous experience has been found to be important in some studies but not in others. Our understanding of how site selection operates is thus limited.

\section{CONCLUSION}

In most circumstances, the overall diet obtained by the grazing ruminant is a combination of bite and site selection. The major ecological paradigm applied to the study of site selection has been optimal foraging theory. Optimality theory is associated with the evolutionary concept that natural selection leads to adaptation and to the extent that ruminants can occupy niches. Even within the limited nature of temperate grasslands there is evidence of niche occupancy which suggests that there is merit in the approach. Optimal foraging implies constraints and those of plant and animal origin are now being described. However, the application of classical foraging theory to bite selection is problematic since it is difficult to identify the significance of individual foraging choices associated with $10-40000$ bites daily. The significance of switching in site selection. which may also involve a bout of bite selection, as described previously, implies that foraging models of site selection require to take more note of bite selection than they currently do. As Belovsky et al. (1989) recently pointed out 'appropriate foraging models are likely to be more complex than classical models. The aim must be to employ appropriate models based on given food distribution observed in the field and then ask whether foragers choose an optimal diet under these circumstances.' This is the challenge that requires to be met to understand diet selection in large herbivores.

\section{REFERENCES}

Arnold, G. W. (1970). Regulation of food intake in grazing ruminants. In Physiology of Digestion and Metabolism in the Ruminart. pp. 264-276 [A. T. Phillipson, editor]. London: Oriel Press.

Arnold, G. W., McManus, W. R., Bush. I. G. \& Ball, J. (1964). The use of sheep fitted with oesophageal fistulae to measure diet quality. Australian Journal of Experimental Agriculure and Animal Husbandry' 4. $71-79$.

Barthram, G. T. \& Grant, S. A. (1983). Defoliation of ryegrass-dominated swards by sheep. Grass and Forage Science 39, 211-220.

Belovsky, G. E., Ritchie, M. E. \& Moorehead. J. (1989). Foraging in complex cnvironments: whin prey availability varics over time and space. Theoretical Population Biology 36, 144-160.

Burlison. A. J. (1987). Sward canopy structure and ingestive behaviour in grazing animals. PhD Thesis. University of Edinburgh.

Burlison, A. J., Hodgson, J. \& Illius, A. W. (1991). Sward canopy structure and the bite dimensions and bite weight of grazing sheep. Grass and Forage Science (In the Press.)

Demment, M. W. \& Van Soest, P. J. (1985). A nutritional explanation for body size patterns of ruminant and non-ruminant herbivores. American Naturalist 125, 641-672.

Flores. G. R., Provenza, F. D. \& Balph, D. F. (1989a). Role of experience in the development of foraging skills of lambs browsing the shrub, service berry. Applied Animal Behaviour Science 23, 271-278.

Flores, G. R., Provenza. F. D. \& Balph, D. F. (1989b). The effect of experience on the foraging skill of lambs: importance of plant form. Applied Animal Behaviour Science 23, 285-291.

Gordon, I. J. (1989). Vegetation community selection by ungulates on the Isle of Rhum. III. Ieterminants of vegetation community selcction. Journal of Applied Ecology 26, 65-79.

Gordon, I. J. \& Iason, G. R. (1989). Foraging strategy of ruminants: its significance to vegetation utilisation and management. Macaulay Land Use Research Institute Annual Report, 1989, pp. 34-41. 
Gordon. I. J. \& Illius, A. W. (1988). Mechanisms of diet selection in ruminants: structure of the incisor arcade. Functional Ecology 2, 15-22.

Grant, S. A. \& Hodgson, J. (1986). Grazing effects on species balance and herbage production in indigenous plant communities. In Grazing Research at Northern Latitudes. NATO ASI Series A, vol. 1078. pp. 69-77 [O. Gudmundsson, editor]. New York: Plenum Press.

Gunn, R. G., Smith, W. F.. Senior, A. J., Barthram, E. Sim, D. A. \& Hunter, E. A. (1991). Premating herbage intake and the reproductive performance of North Country Cheviot ewes in different levels of body condition. Animal Production 52, 149-156.

Hodgson, J. (1971). The development of solid food intake in calves. 1. Effect of previous experience of solid food, and the physical form of the diet. on the development of food intake after weaning. Animal Production 13, 15-24.

Hodgson, J. (1981). Variation in the surface characteristics of the sward and the short-term rate of herbage intake by calves and lambs. Grass and Forage Science 36, 49-57.

Hunter, R. F. (1962). Hill sheep and their pasture: a study of sheep grazing in South East Scotland. Journal of Ecology 50, 651-680.

Illius, A. W. \& Gordon, I. J. (1987). The allometry of food intake in grazing ruminants. Journal of Applied Ecology 56, 989-1000.

Illius, A. W. \& Gordon. I. J. (1989). Constraints on diet selection and foraging behaviour in mammalian herbivores. In Behavioural Mechanisms of food Selection, pp. 371-393 [R. N. Hughes, editor]. Berlin: Springer-Verlag.

Krueger, W. C., Laycock. W. A. \& Price, D. A. (1974). Relationships of taste, smcll, sight and touch to forage selection. Journal of Range Management 27, 258-262.

Lobato, J. F. P., Pearce, G. R. \& Bcilhartz, R. G. (1980). Effect of early familiarisation with dietary supplements on the subsequent ingestion of molasses-urea blocks by sheep. Applied Animal Ethology 6, 175--183.

Lynch. J. J., Keogh, R. G., Elwin, R. L., Green, G. C. \& Mottershead, B. E. (1983). Effects of early experience on the post-weaning acceptance of whole-grain wheat by finc-wool merino lambs. Animal Production 36, 175-183.

Milne, J. A., Bagley, L. \& Grant, S. A. (1979). Effect of season and level of utilisation on the utilisation of heather. 2. Diet selection and intake by sheep. Grass and Forage Science 34, 45-53.

Milne, J. A. \& Grant, S. A. (1987). Sheep management on heather moorland. In Efficient Sheep Production from Grass, pp. 165-167 [G. E. Pollott, editor], British Grassland Society Occasional Symposium 21, $165-167$.

Milne, J. A., Hodgson, J., Thompson, R., Souter, W. G. \& Barthram, G. T. (1982). The dict ingested by sheep grazing swards differing in white clover and perennial ryegrass content. Grass and Forage Science 37, 209-218.

Milne, J. A., MacRae, J. C., Spence, A. M. \& Wilson, S. (1978). A comparison of the voluntary intake and digestion of forages at different times of the year by the sheef and red deer (Cervus elaphus). British Journal of Nutrition 40, 347-357.

Milne, J. A.. Maxwell, T. J. \& Souter, W. G. (1981). The effect of supplementary feeding and herbage mass on the intake and performance of grazing ewes in early lactation. Animal Production 32, 185-195.

Provenza, F. D. \& Malechek, J. C. (1986). A comparison of food selection and foraging behaviour in juvenile and adult goats. Applied Animal Behavioural Science 16, 49-61.

Robbins, C. T., Mole, S., Hagcrman, A. E. \& Hanley, J. A. (1987). Role of tannins in defending plants against ruminants: reduction in dry matter digestion. Ecology 68, 1606-1615. 